\title{
The Impact of the Panorama on Contemporary Sculpture and Installation - The Panorama in the Development of the Perspective-
}

\author{
ABSTRACT \\ I. Introduction: The Egocentric image \\ 1I. Historical point of view and its transformations \\ 1. Natural hierarchies \\ 2. The central point \\ 3. Surrounding the central point \\ 4. The disperse of the concentric system \\ III. Techniques and theoretical background of the panorama \\ 1. Methods of creating a panoramic image \\ 1) Stitching a full panorama image with several single shots \\ 2) Line scan system \\ 3) True One-shot systems \\ 4) Moving "one-shot systems"(Google street view ) \\ 2. Linking the image with space \\ 1) Projection systems \\ 2) Texture mapping, UV mapping \\ IV. Examples in contemporary art and practical use of panorama \\ 1) Analogous virtual space \\ 2) Psychotic virtual tour \\ 3) Movable image \\ 4) Moving points of view installation \\ $\checkmark$. Conclusion \\ Bibliography
}

Bernd Halbherr*, Yoo Jong Yoon

\section{초 록}

본 논문은 현대 미술에서 조형과 설치 작업을 중심으로 하는 파노라마 이미지를 활용한 접근과 개발에 관한 연구이다. 본문에서 제시된 작품들은 현대예술의 작품에서 추출된 예시들로 본 연구와 적합한 합리적인 범주에서 추출된 대표적인 예시를 채택하여 설정하고자 하였다. 또한 원근법의 역 사적이고 전통적인 개념인 간략화의 방법은 기술적 연구를 통하여 파노라마의 형식으로 발전시켜 본 연구와 접목 가능하도록 설명하고자 하였다.

현대미술에서 파노라마 기법은 다른 2 차원과 3 차원 사이의 분리된 간극이 서로 연결이 가능한지 에 대한 의문과 그 가능의 여부에서 나타나는 간극의 차이를 3 차원으로 설명 및 이해가 가능하도록 펼침과 조합이라는 파노라마 형식으로 재현하고자 하였다. 이로써 성향이 서로 다른 두 개의 차원 을 시각적 존재로서 연결하는 고리의 역할로 작용되고 있음을 기술적으로 재현하고 설명하고자 하 였다. 뿐만 아니라, 이러한 파노라마형식은 다소의 관계성이 존재하지만 종국에는 2 차원과 3 차원이 라는 개념으로 서로 동떨어진 차원에 대한 차이점으로 존재하게 된다. 이러한 간극이 다름과 통합. 연결과 확장 그리고 분리와 접합 등에 대한 공간의 일치와 불일치에 대한 철학적 논제의 화두가 될 가능성도 존재한다. 따라서 본 연구에 대한 주요한 관심과 시작의 계기는 현시대성이 가지는 복잡 하고 다양한 사회구조와 이러한 사유에서 발생되는 철학적 의미들과 가치, 그리고 그러한 가치에서 파생되어 제시되고 제안되는 언어적 표현으로 어떻게 사회를 바라봐야 하는가에 대한 시점 혹은 관 점의 이해방법들, 그리고 이러한 의문의 연결선 상에서 사회활동에서 무심코 스쳐지나가는 시각적 구조와 그 구조물과 대면했을 때 의문시 되는 다양한 의견과 차원의 다름이 서로 연결되고 통합하 여 시각적으로 표현이 가능한가? 등으로 고민하던 개인적 견해에서부터 시작되게 되었다.

결론으로 언어적 해석으로 우리가 살아가며 해석이 다양한 공간의 차원이 원근법을 활용한 파노 라마의 작품들로 시대성을 반영하는 거울적 이해는 가능할 것인가? 그리고 파노라마의 형상을 통해 창의적 심미성을 시각적으로 창조가 가능할 것인가? 에 대한 의문과 이해를 조형작품과 설치작품의 예시를 통해 시각적 효과와 영향을 확인하며 조망하고자 하였다.

주제어: 파노라마, 이미지, 원근법, 설치, 조형 


\section{I . Introduction: The Egocentric Image}

The Panorama image is a conceptual development of our visual culture, originated in the development the visual perspective. Its influence on our perception of space and consciousness of the viewpoint of the spectator evolved during the formation of the perspective. There are different subcategories of perspectives and they all have an impact on the understanding of the perspective as we know it today. One keynote of this thesis is the fact that the contemporary notion of perspective is mirroring the actual zeitgeist and creates a visual aesthetics. ${ }^{1}$ ) The inner architecture of the panorama - central standpoint of the spectator and the spherical order of the surrounding - is not only the closest form of describing our surrounding in the most realistic way, it seems also an allusion to our social perception. With this research I want to prove that the panorama is a visual concept that influences contemporary sculpture and even coins our self-image in the society. Robert Baker strived for an "entire view" of the human being with his patent for the panorama during his era,2) while our time is a period where the personal character and mind seem to have priority to the social connections and relationships. This "ego-centrism" describes a constellation where a person is convinced to be the center of attention in its

* 본 연구는 중앙대학교 교내학술연구비 지원과제 임. This study is supported by the Chung-Ang University academic research projects.

1) Thomas Hensel about Erwin Panowsky: Perspective as a Symbolic Form Das Raumbild, Bilder jenseits ihrer Flächen, Wilhelm Fink Verlag, 2009, p. 164

2) Robert Bakers publicized panorama patent in 1787, printed in Heinz Buddemeier: Panorama, Diorama, Photographie, Entstehung und Wirkungen neuer Medien im 19.Jahrhundert, Muenchen, 1970 pp.163-164 
social system. At the same time, the individual neither is interested in putting up an absolute hierarchy towards its social environment nor being dependent on the admiration of its social surrounding. It is rather a singularity of its position in the daily life that finds this sensation of being the center. Through the rationality of our logical thinking and the fact that the world gets more and more mathematical - one day everything is being described by numbers - this logical construction of one single central point nowadays dissolves from its concentric position to multiple points of view. Mirroring the social tendencies we end up in the present where singularity of the individual is divided to multiple appearances of locations and attitudes.

This is where my personal interest started and the research of the relevant links within our society began. The importance of visual concepts as it can be seen in the panorama image is based on my conviction that there is a connection between our methodical way of thinking and the aesthetical, philosophical procedures within our society. For this research, I observed historical backgrounds of the development of the perspective and quoted samples of artworks from our period to explain my conclusion. The thesis focuses on the concept of the panorama and shows its impact on contemporary sculpture and society.

\section{Historical point of view and its transformations}

To analyze the context between the panorama and the changes of the perspective, the main chapter starts with a brief summary of the historical development of the perspective. 


\section{Natural hierarchies}

In archaic drawing and painting the meaning of objects and characters was often coined by the position in the images, therefore the "vertical perspective" was an initial way of depicting things. The meaning of size and position was rather critical more than the effort to reach an illusionary impression.

During the ancient Greece period first attempts of illusionism with wall paintings in public and private buildings appeared, known as "Skenographia".3)

These compositions were created through the antiquity by developing a hierarchical order system in terms of size and color that is connected to the "real" perception of space. These were the first approximations to the definition of real ism. ${ }^{4)}$

\section{The central point}

The visual creation of an image shows us the philosophical background of the time in which it was created. During the middle ages, the skills of the perspective got so perfectly researched therefore during these times, it sparked the logical connection to the panorama as we know it nowadays.

I was always interested in the correlation of images towards the human society. Certain understandings of concepts of philosophical backgrounds reflect the status-quo of the sub consciousness of the community.

In 1435, Leon Battista Alberti published his writing "Della Pitture" (On Painting), from that time on the

3) Walker, John (1992) "Scenography", Glossary of Art, Architecture \& Design since 1945, 3rd. ed.

4) McKinney, Joslin (2009), The Cambridge Introduction to Scenography, Cambridge: Cambridge University Press, p.4. 
knowledge of linear perspective could be spread throughout the western culture not only by hearsay but with the means of a reproducible media and it became influential on art and philosophy alike. That meant the liberation from the multiple viewpoints of the medieval art towards the fixed viewpoints of the individual viewer. It also opened the door to the individualism of the Humanism of the Renaissance as we know it. Cases like Albrecht Duerer' s “Zeichner des liegenden Weybes" < fig.1> from 1538 show obviously the point of view and its relation between the viewer and the object.5)

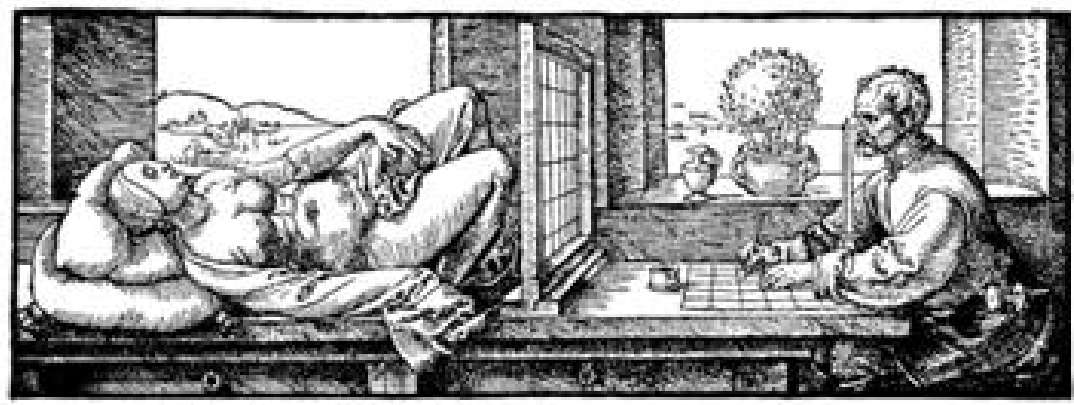

fig 1. Albrecht Duerer "Zeichner des liegenden Weybes" , woodcut, 1538

Nowadays the classical idea of the linear perspective lost his absolute status due to our dynamic society with steadily moving multiple points of view.6)

5) Hirsch, Vanessa, Das Raumbild, Bilder jenseits ihrer Flächen, Wilhelm Fink Verlag,2009 s.101

6) Steyer 1, Hito 2011 e-flux New York In Free Fall : A Thought Experiment on Vertical Perspective http://www. e-flux.com/journal/in-free-fall-a-thought-exper iment-on-vert i cal-perspective/ 


\section{Surrounding the central point}

Robert Baker is usually listed as the inventor of the panorama, he was researching this concept since 17807) and developed it to an architectonic structure on which he got a patent on the 19th of June 1787.8) Another key figure also was Louis Jacques Mande Daguerre(1787-1851).9) He was inventing and developing the Diorama as a stage design. The heydays of the big sized panoramas at the end of the 19th century describe the aim of a society for a perfect illusion. This conviction was also based on believing that through technical development anything can be reached and one day the reality might be replaced by futuristic visions for the sake of a better society. Later these ideas were replaced by the acknowledgment, that a society is much more complex than only the scientific and economical status. Within the critics and the crisis of the modern society after the end of the 19th century the interest of the perfect illusion seems to disappear. This results in a loss of interest in the presentation of the strongest illusion and the decay is even more supported with the beginning of the abstraction and conceptional art during this time. Another reason for the vanishing might be that realism itself became a usual standard in many media of arts such as painting, photo, film, and video. Also computers and mobile phones supplied a simple and efficient way of creating panoramic views in an inexpensive and easy producible way so

7) Hyde, Ralph Sehsucht, Das Panorama als Massenunterhaltung im 19. Jahrhundert 1993, Ver lag Stroemfeld/Roter Stern, p.132

8) Oettermann, Stephan Das Panorama. Die Geschichte eines Massenmediums. Syndikat, Frankfurt/Main, 1980,p.79

9) Daniels, Barry Sehsucht, Das Panorama als Massenunterhaltung im 19. Jahrhundert 1993 Verlag Stroemfeld/Roter Stern p.37 
that the sensation of the panorama disappeared in the eye of the average spectator.

\section{The disperse of the concentric system}

Virtual tours and panoramic views like Google Street view were provoking a very new point of view in the development of the perspective. Within the technical developments of visual media different viewpoints can exist in the same constellation. The perspective becomes decentralized.

\section{Techniques and theoretical background of the panor ama}

To understand the panorama structure in itself I will explain the basic technical background as well as applications in projection systems.

\section{Methods of creating a panoramic image}

There are three main techniques relevant in the field of creation for explaining this research.

\section{1) Stitching a full panorama image with several single} shots

The most common way of creating panoramas is the way of "stitching" images. There are vast varieties of stitching programs existing nowadays. Basically, they use all the same techniques: Several overlapping images are stitched together. The computer controls the overlapping areas with a special algorithm and creates control points (similarities) that are used to stitch and change the images angle to the angle of the projection (graphics) this technique is the 
usual way to create "non moving images" panoramas.

One of the most influential freeware programs was developed by Helmut Dersch mathematics and physics professor in Germany. 10) His "Panotools" software that he started in 1998 was used by different open source projects and is still alive within various software that are available on the market.11) The basic principles of stitching software are pretty similar. First you have to take photographs as many as needed that overlap each other at least 20 percent. The pictures have to be taken on a tripod with a specific panorama head. Only this way it is sure that there will be no blending mistakes between the pictures that can be caused by non-centered nodal points. The algorithm of the software analyzes the images and creates automatically control points that will be the criteria for connecting the single pictures. All the images must be taken in a manual mode that doesn't change any values of exposure, focus, apertures and white balance. That way is guaranteed that there are no differences between the single images as mentioned before.

\section{2) Line scan system}

The line scan systems use the idea of scanning the picture "line by line" and completing it to a full panoramic image instead of using overlapping images, this technique exist in diverse mixtures including the round shot version that result in very high-resolution images. ${ }^{12)}$

10) Dersch, Helmut 2015 http://webuser.hs-furtwangen.de/ dersch/

11) Dersch, Helmut 2002 http://www.panotools.org/dersch/

12) Seitz Roundshot 2015

ht tp://www.roundshot.com/xml_1/internet/en/applicat ion/d77/d89/f90.cfm 


\section{3) True One-shot system}

As a "one-shot-system" we understand techniques were no stitching or any other calculation is involved in the process.13) Usually this is done by the means of mirror or lens system, and it ends up in a lower resolution system, but combinable with moving images like video. ${ }^{14)}$

\section{4) Moving "one-shot system" (like google street view)}

Since the cameras themselves are that expensive anymore in latest approaches the single lens conversion is replaced by the use of several cameras that are orientated in a central point, and the final image is calculated together synchronously. The advantage is higher resolution of the images at the same time being able to record video or just use it as a still image panorama.

\section{Linking the image with space}

To explain the relation between space and image, there is the need to observe the functions like projection systems and mapping.

\section{1) Projection system}

Projection systems are important for understanding how an image matches certain special shapes. ${ }^{15)}$ Historically they go back to examples like Martin Waldseemueller's Globe Segment map from 1507.16) The discovery from 1993 showed as woodcut

13) GoPano Plus 2011

ht tp://www .gopano. com/product s/gopano-plus\#page=t echnology

14) 360fly $2015 \mathrm{https}: / / 360 \mathrm{fly} . \mathrm{com} /$

15) https://en.wikipedia.org/wiki/Map_projection

16) Schneider, Ute, Die Macht der Karten Eine Geschichte der Kartographie vom Mittelalter bis heute, 2012,p.93 
image prepared to match with a spherical form like a globe. Many different map projections with higher accuracy were developed later during the following centuries to fulfill different criteria of the mapping processes and to create more accurate maps on globes or other physical bodies. E.G. the spherical projection is a recalculation from the 3dimensional body formation - the sphere - where the image is ordered 3-dimensionally in the space coordinates, that means any pixel, which is the color information of the bodies surface, that can lay on any 3-dimensional point while the 2-dimensional image as it says represents the image in a 2-dimensional flat space. The same approach, but even more simplified in its geometrical form is the "Dymaxion World" by Buckminster Fuller17) that was introduced first time in 1943 and is sending impulses on creative minds until nowadays. ${ }^{18)}$

\section{2) Texture mapping, UV mapping}

Similar to projection mapping the texture mapping are simplified methods in computer systems for defining an image that is used for displaying surface information by attaching the mapping on a $3 \mathrm{~d}$ body. The $\mathrm{U}$ and $\mathrm{V}$ coordinates are the variables of the mapping image that actually represent the $\mathrm{x}^{-}$and $\mathrm{y}^{-}$axes of the image, but in $3 \mathrm{~d}$ computer programs they cannot be used because $x_{-} y_{-} z$ are usually reserved to describe the 3 -dimensional space.

17) “Life present R. Buckminster Fuller' s Dymaxion World” . LIFE Magazine: March 1943, pp,41-55

18) "DYMAX REDUX Winner", The Buckminster Fuller Institute, http://bfi.org/2014 


\section{Examples in contemporary art and practical use of panor ama}

To undermine the influential strength of the panorama image on contemporary media and installation artworks I selected some representing positions in fine arts and a sample of their practical use.

\section{Analogue virtual space}

Within my installation in the gallery space "Laden" in Düsseldorf 2004,<fig.2> I used a panorama image taken outside the gallery space to placard the complete exhibition space. This way the viewer gets the impression of standing outside in front of the gallery. The exhibition space was entirely reconstructed on a 3D program and the panorama was used as a spherical texture mapping, so the viewer was able to enjoy a completed aligned perspective view in the center of the room.

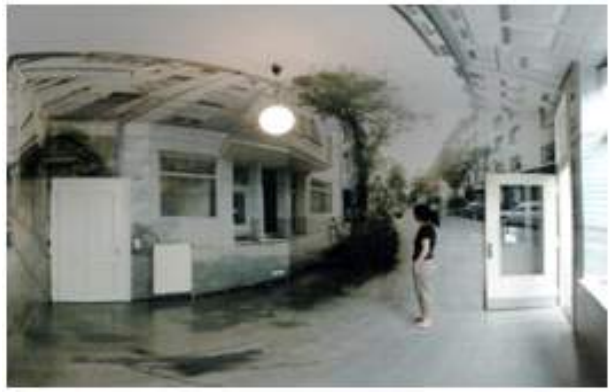

fig 2. Bernd Halbherr, "Laden" in Düsseldorf 2004 Installation view, the space is completely placarded with a 360 degree panorama. 


\section{Psychotic virtual tour}

In his installation So.So.So Maurice Benayoun <fig.3> creates a fusion between synchronized realities and locations. The visitors use VR binoculars to experience panoramic images that were taken at the same time in different locations, representing life moments of different persons at a certain day at the same moment 7.47 AM. The images fade partially between the different locations, so the realities get mixed while still the spectator feels like being the center of the spatial experience. 19)

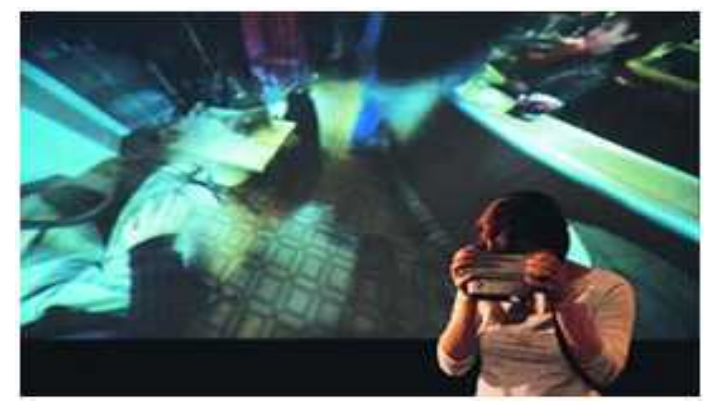

fig 3. Maurice Benayoun "So.So.So" 2003.

The spectator uses VR binoculars to experience the panorama movies, the content is also projected on the wall of the exhibition space.

\section{Movable image: Place - Ruhr Jeffrey Shaw}

In his installation "Place - Ruhr" $<$ fig.4> for the Vision Ruhr in Dortmund, Germany in 2000 the Artist Jeffrey Shaw uses a rotating platform that allows the spectator interactively move a projected image within a large circular

19) Benayoun, Maurice, http://www.benayoun.com/projet.php?id=25 So.So.So 2003 
projection screen. The work shows virtual landscapes in the Ruhr area that can be selected with the means of an underwater camera that functions as the main interface within the installation. On the screen of the interface, there is a map of the connected sites and the microphone triggers texts phrases that appear on the screen every moment the visitor creates a sound.20)

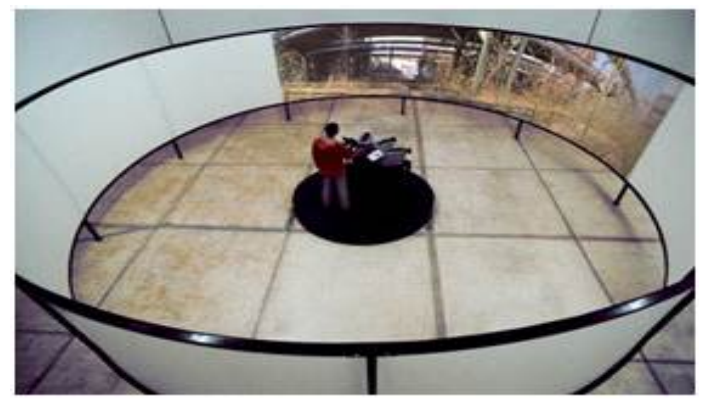

fig 4. Jeffrey Shaw Place - Ruhr 2000. The spectator can move the panorama on a platform around the screen.

\section{Moving points of view installation}

In the installation "City Chapters" <fig.5> the artist 0liver Griem shows several sequences that deal with the themes home, city, paradise, natural vs. artificial environments.21) In the center of the exhibition space, there are mirrors that reflect projected images and movies on the walls. The mirrors can be rotated horizontally and vertically with motors that are controlled with an Arduino

20) Shaw, Jeffrey,

ht tp: //www. jef frey-shaw.net/html_main/show_work.php?record_id=105

21) Catalogue "31 experiments on light: Intimate Rapture" in Culture Station Seoul 284, 2015,pp.38-41 
board and Max. Audio, Photographs, graphics, panoramic images and movies are blended to give the appearance of special media content with moving centers. In terms of perspective, there is a complete dissolution of ordinary viewpoints and linear system. The rhythmical structure built up by sound and movement is replacing the usual order of perspective. 22 )
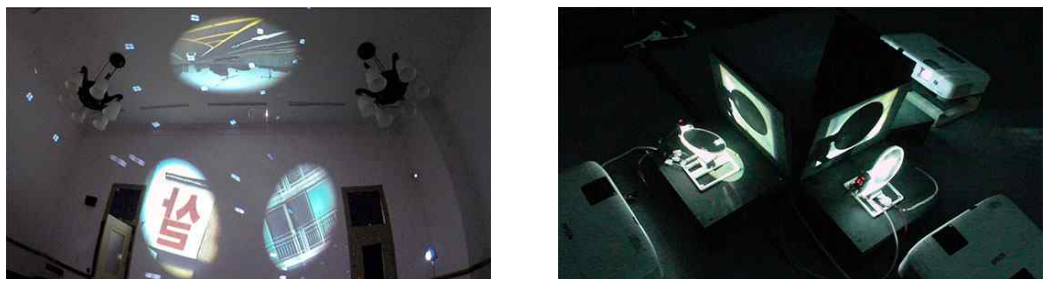

fig 5. Oliver Griem "City Chapters", 2015. Computer controlled moving mirrors project the panorama movies and images according to the composition of the artist.

\section{Panorama becomes social, Street view}

The final concept sample to investigate the development of the panorama: "Street view" <fig.6> was initialized by Google and uses panoramic images to create virtual tours. It can be controlled by the browser user by mouse clicks to navigate through the streets. The data are mostly stitched images by several cameras which are installed on the rooftop of a car. The project was launched in 2007 in urban centers and includes nowadays also rural areas worldwide. Since 2015, there was a partnership to environmental monitoring company Aclima announced. So in the latest development of the panorama not only visual aspects are meaningful, also

22) Griem, Oliver,http://f ischkalb.com/Data/CityChapters/index.html 2015 
the "invisible" data of environmental pollution started to create a new layer in the history of virtual tours.23)

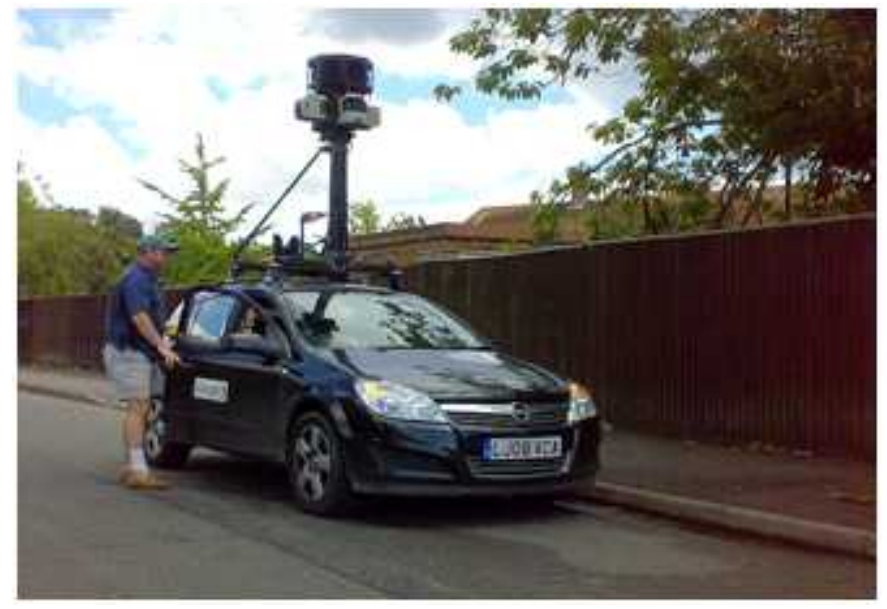

fig 6. Google, "Street view" 2015. The latest version will be combined with data of environmental pollution.

\section{Conclusion}

The panorama image picture has a unique position in the field of visual perception and depiction because of its centralistic inner structure. Originally it was constructed by Baker as a concept of the "entire view". Nowadays in the 21st century it is reflected as the concentric way of thinking and depicting one owns reference place in the society. It is a representative with the strongest realistic feeling underneath the patterns of perspectives, thanks to the illusionary space between the individual spectator and

23) Gershgorn, Dave, Popular Science. Retrieved 30 July 2015. ht tp://www. popsci.com/google-will-start-mapping-pol lut ion-same-way-theymap-streets 
the real world. Because of the architecture between the spectator and the image it sets up a kind of 3 dimensional structures that leads to the final impression that the panorama is more than an image itself, it creates space in the viewers mind and puts him virtually into a coordinate system.

Further concepts with multiple points of view are representatives for the moving society wherein the individual character is steadily moving in his multiple shaped surroundings ending up rather in dream worlds or psychedelic clouds than in rational patterns. The panorama creates a special link between 3-dimensional understanding of space and the 2-dimensional matrixes of normal images. Bridging the idea of a complete image to a complete space, it is also a conjunction between idea, reality and illusion. With the development of the techniques the inner meaning and associated definitions of the term panorama have changed.

While the first development steps originated in the idea of developing the understanding of the linear perspective, the further steps are based on the rational conclusions of the viewers' standpoint(the consciousness of the viewer and its position) and the understanding of linking the space and the image.

What becomes later transparent - due to the techniques of computer programs - the images as a mapping of three-dimensional coordinates, was first of all a fascination of understanding the visual techniques of perspective and the goal of creating the ultimate illusion. In the age of the diorama, the panorama held its central position as a main technique of joining the illusionary feeling of space with the image. 
Nowadays new techniques transform our sensation of the panorama into extended philosophical levels. The use of "street views" (as Google or similar firms as Daum and Naver) transforms the perception of the panorama to a fluid polycentric organism. Virtual tours are a contemporary system of creating and experiencing 3-dimensional spaces and within there the panorama still holds a fundamental position. But as an extension these virtual tours also other dimensions of time and movement are involved as the spectator can move virtually through these streets.

With the digitalization, the magical and illusionary moment of the panorama changed to a mundane, widely accepted and standardized custom of using it in our daily life. Especially the technical automation within the mobile phones leads to a broad distribution of the extraordinary flavor of the panorama as an image idea. So philosophically a new normalized generation of panoramic photography has been initiated. The centric point of view with the reality surrounding it became a classical understanding of our contemporary perspective. At the same time, the centralistic architecture of the panorama seems to disappear in the restless movements of our society. Changing viewpoints replaced the static character and transformed the world into a fluid organism. Finally, the ego dissolves in the mass of the individualism as the architecture of reality is changing steadily.

\section{Bibl iography}

"DYMAX REDUX Winner", The Buckminster Fuller Institute, [Online] 
2014. http://bfi.org/.

"Life presents R. Buckminster Fuller's Dymaxion World", [ LIFE Magazine]. 1943, pp. 41-55.

360fly. Roundshot video technique. [Online] 2015. ht tps://360f ly.com/.

Benayoun, Maurice, 2003, So.So.So., artist homepage, [Online] 2003. ht t $\mathrm{p}: / /$ www . benayoun. com/projet . php?id=25.

Buddemeier, Heinz, Panorama, Diorama, Photographie, Entstehung und Wirkungen neuer Medien im 19.Jahrhundert. Munich 1970, pp. 163-164. about Robert Bakers publicized panorama patent in 1787.

Daniels, Barry. Sehsucht, Das Panorama als Massenunterhaltung im 19. Jahrhundert

Stroemfeld / Roter Stern, 1993, p.37.

Dersch, Helmut, Immersive Imaging. Articles and software Prof. Dr.

H. Dersch - HFU Furtwangen. [Online] 2015,

ht tp://webuser. hs-fur twangen. de/ dersch/.

Panorama Tools. panotools. [Online] 2002.

http://www. panotools.org/dersch/.

Gershgorn, Dave. Google will start mapping pollution the same way they map streets. Popular Science. [Online] 2015. http://www.popsci. com/google-will-start-mapping-pol lut ion-same -way-they-map-streets

GoPano Plus. [Onl ine] 2011.

ht tp://www. gopano. com/product s/gopano-plus\#page=technology .

Griem, Oliver. "31 experiments on light: Intimate Rapture". Culture Station Seoul 284, 2015, pp. 38-41.

Griem, 01iver. City Chapters. [Online] 2015.

http://fischkalb.com/Data/CityChapters/index.html

Hensel, Thomas. Das Raumbild, Bilder jenseits ihrer Flächen. Munich

: Wilhelm Fink Verlag, 2009, p. 164. about Erwin Panowsky:

Perspective as a Symbolic Form.

Hirsch, Vanessa, Das Raumbild, Bilder jenseits ihrer Flächen . s.l.

: Wilhelm Fink Verlag, 2009, p. 101. 
Hyde, Ralph. Sehsucht, Das Panorama als Massenunterhaltung im 19. Jahrhundert. Stroemfeld/Roter Stern, 1993, p. 132.

McKinney, Joslin. The Cambridge Introduction to Scenography. Cambridge : Cambridge University Press, 2009, p. 4.

Oettermann, Stephan. Das Panorama Die Geschichte eines Massenmediums. Frankfurt/Main :

Syndikat, 1980, p. 79.

Schneider, Ute. Die Macht der Karten. Eine Geschichte der Kartographie vom Mittelalter bis heute. Darmstadt : Primus Ver lag, 2012, p. 93.

Seitz Roundshot. fast 360 degree equipment. [Online] 2015. http://www.roundshot.com/xml_1/internet/en/application/d77/d89 /f90.cfm.

Shaw, Jeffrey. Place - Ruhr. artist homepage. [Online] 2000. ht tp://www. jeffrey-shaw.net/html_main/show_work.php?record_id= 105.

Steyerl, Hito. In Free Fall: A Thought Experiment on Vertical Perspective, e-flux New York, [Online] 2011.

http://www.e-flux.com/journal/in-free-fall-a-thought-exper imen t-on-vertical-perspective/.

Walker, John, "Scenography". Glossary of Art, Architecture \& Design since 1945. Vol. 3rd. ed. 1992.

Wikipedia, the free encyclopedia. [Online] 2015.

https://en.wikipedia.org/wiki/Map_projection 


\title{
ABSTRACT
}

\section{The Impact of the Panorama on Contemporary Sculpture and Installation -The Panorama in the Development of the Perspective-}

\author{
Bernd Halbherr · Yoo, Jong-Yoon
}

This thesis is research about the development and application of the panorama image in contemporary artwork, focusing on sculpture and installation. The samples of artworks are a selection of representatives from numerous examples of works that cannot be introduced without exceeding a reasonable scope of the thesis. A brief outline of the historical concepts of the perspective will describe the development of the panorama in itself. Some technical explanations and the practical use of the panorama with its link to 3-dimensional applications should bridge the explanation gap between the 2nd and 3rd dimensional usage of the panorama in contemporary artwork. Furthermore, some philosophical statements are proposed in the discussion. One of the main interests and initial motivation of this study was my personal believe that there is always a relationship between social philosophical values and the way a society sees or encounters visual structures. In other words the contemporary understanding of space and perspective is mirroring the actual zeitgeist and creates an exemplary visual aesthetics.

Key Word : Panorama, Image, Perspective, Installation, Sculpture 
Bernd Halbherr Professor of Chung-Ang University, College of Arts, Faculty of Fine Art, Major Sculpture Gyeonggi-Do Anseong-Si, Gongdo-eup, Bangjukgil 10-11 e-mail: berndhalbherr@cau.ac.kr Yoo Jong Yoon Graduate school of Chung-Ang University, College of Arts, Faculty of Fine Art, Major Sculpture Incheon Metropolitan City Yeonsu-Gu Cheonghangno 12th Street Nr. 301 e-mail: x2dc@naver.com

논문투고일 : 2015.10.29. 심사종료일 : 2015.11.19. 게재확정일 : 2015.11.26. 